\title{
Signalling pathways involved in the stimulation of glycogen synthesis by insulin in rat hepatocytes
}

\author{
M. Peak ${ }^{1}$, J.J. Rochford ${ }^{2}$, A.C. Borthwick ${ }^{2}$, S.J. Yeaman ${ }^{2}$, L. Agius ${ }^{1}$ \\ ${ }^{1}$ Department of Medicine, The Medical School, University of Newcastle upon Tyne, UK \\ ${ }^{2}$ Department of Biochemistry and Genetics, The Medical School, University of Newcastle upon Tyne, UK
}

\begin{abstract}
Summary In hepatocytes glycogen storage is stimulated by insulin and this effect of insulin is counteracted by epidermal growth factor (EGF). The mechanism by which insulin stimulates glycogen synthesis in liver is unknown. We investigated the involvement of candidate protein kinases in insulin signalling in hepatocytes. Both insulin and EGF activated extracellular regulated kinase 2 (ERK-2), p70 ${ }^{\text {rsk }}$ and protein kinase $\mathrm{B}(\mathrm{PKB})$ and inactivated glycogen synthase kinase-3 (GSK-3). Whereas EGF caused a greater activation of ERK-2 than insulin, the converse was true for PKB. The stimulation by insulin of ERK-2 was blocked by a mitogen-activated protein (MEK) inhibitor (PD 98059) and of p70 ${ }^{\text {rsk }}$ by rapamycin. However, these inhibitors, separately or in combination, did not block the stimulation of glycogen synthesis by insulin, indicating that activation of these kinases is not essential for the stimulation of glycogen synthesis by insulin. Mono Q fractionation
\end{abstract}

of hepatocyte extracts resolved a single myelin basic protein (MBP) kinase peak from extracts of EGFtreated cells (peak 1, eluting at $200 \mathrm{mmol} / \mathrm{l} \mathrm{NaCl}$ ) and two peaks from insulin-treated cells (peak 1 eluting at $200 \mathrm{mmol} / \mathrm{l} \mathrm{NaCl}$ and peak 2 eluting at $400 \mathrm{mmol} / \mathrm{l} \mathrm{NaCl}$ ). In the combined presence of insulin and EGF, activation of peak 2 was abolished. In situ MBP kinase assays and immunoblotting established that peak 1 coincides with ERK-2 and peak 2 is not an activated form of ERK-1 or ERK-2. It is concluded that $\mathrm{PKB}$, which is activated to a greater extent by insulin than EGF, and peak 2, which is activated by insulin and counteracted by EGF, are possible candidates in mediating the stimulation of glycogen synthesis by insulin. [Diabetologia (1998) 41: 16--25]

Keywords Insulin, epidermal growth factor, glycogen synthesis, protein kinases, hepatocytes (rat).
Insulin regulates blood glucose homeostasis by stimulating the utilization of glucose by liver, muscle and adipose tissue. In the liver insulin stimulates glycogen

Received: 24 April 1997 and in revised form: 26 August 1997

Corresponding author: Dr. L. Agius, Department of Medicine, The Medical School, Newcastle upon Tyne, NE2 4HH, UK Abbreviations: EGF, Epidermal growth factor; ERK, extracellular regulated kinase; GSK-3, glycogen synthase kinase-3; MAP kinase, mitogen-activated protein kinase; MAPKAP-2, mitogen-activated protein kinase-activated protein kinase-2; MBP, myelin basic protein; MEK, mitogen-activated protein kinase kinase; PI-3 kinase, phosphatidylinositol 3'-kinase; $\mathrm{PKB}$, protein kinase B; $\mathrm{p} 70^{\mathrm{rsk}}$, ribosomal S6 kinase $1 ; \mathrm{p} 90^{\mathrm{rk}}$, ribosomal S6 kinase 2 . synthesis, glycolysis and fatty acid synthesis, but unlike the situation in muscle and adipose tissue it does not stimulate glucose transport. The conversion of glucose to glycogen in liver cells is dependent on the extracellular glucose concentration and on the presence of insulin, which stimulates glycogen synthesis over a wide range of glucose concentrations [1]. However, the mechanism by which insulin stimulates glycogen synthesis in liver is unknown. We have characterized a hepatocyte in vitro system to study the metabolic effects of insulin and the corresponding signalling mechanisms [2--4]. This experimental model shows similar time courses of glycogen deposition in response to substrates and insulin [2] as are observed in vivo [5]. The stimulation of glycogen synthesis in this 
model is associated with activation of glycogen synthase [6].

Various hypotheses have been proposed to explain the stimulation of glycogen synthase by insulin in extrahepatic tissues, and a number of serine kinases have been implicated. There is increasing evidence that there are tissue-specific differences in the involvement of at least some of these kinases in the control of glycogen synthesis by insulin [7--11]. Stimulation of glycogen synthesis by insulin in muscle was postulated to be via mitogen-activated protein (MAP) kinase-dependent phosphorylation of $\mathrm{p} 90^{\mathrm{rsk}}$ which in turn phosphorylates the glycogen-binding subunit of protein phosphatase-1 (PP-1G) [12] or glycogen synthase kinase-3 (GSK-3) [13], leading to activation of glycogen synthase. MAP kinase and $\mathrm{p} 90^{\mathrm{rsk}}$ were also shown to be rapidly activated in liver following acute infusion with insulin and have been implicated in mediating the physiological effects of insulin in the liver [14]. However, studies in extrahepatic tissues using the mitogen-activated protein kinase kinase (MEK) inhibitor PD 98059 have suggested that MAP kinase is not involved in the stimulation of glycogen synthesis by insulin $[9,11,15,16]$.

Two additional pathways for inactivation of GSK3 have been proposed. One of these involves $\mathrm{p} 70^{\text {rsk }}$ which is activated by insulin in various cell types [7-11]. Evidence for the involvement of $\mathrm{p} 70^{\text {rsk }}$ in the regulation of glycogen synthesis, based on the use of the inhibitor rapamycin, has been reported for myoblasts [9] and diaphragm [11] but not for freshly isolated adipocytes [7], suggesting tissue differences for this pathway between muscle and adipose tissue. In addition different effects of rapamycin have been reported in different cell lines $[8,10]$ suggesting that the degree of cellular differentiation may also be critical for the utilization of $\mathrm{p} 70^{\mathrm{rsk}}$ by insulin in the activation of glycogen synthase. The role of $\mathrm{p} 70^{\text {rsk }}$ in mediating the actions of insulin on glycogen synthesis in hepatocytes has not yet been investigated. Another pathway that has been proposed to regulate glycogen synthesis in extrahepatic tissues involves the protein kinase $\mathrm{Akt} / \mathrm{Rac}$, also referred to as protein kinase B (PKB) $[9,12]$. However, no studies to date have examined the regulation of PKB and GSK-3 by insulin in the liver. Whether any of these kinases mediate the effects of insulin on the activation of hepatic glycogen synthesis is as yet unknown.

The aim of this study was to investigate the role of ERK-2, p70 ${ }^{\text {rsk }}$ PKB and GSK-3 in the regulation of glycogen synthesis by insulin in hepatocytes. We have compared the actions of insulin with the effects of epidermal growth factor (EGF), which is a potent mitogen in hepatocytes and like other growth factors [6], potently counteracts the stimulation of glycogen synthesis by insulin $[17,18]$. A comparison of the effects of insulin and EGF on protein kinase activation in hepatocytes is therefore a potential approach to identify the signalling pathways that are involved in the regulation of glycogen synthesis as distinct from those involved in stimulation of cell growth and proliferation.

\section{Materials and methods}

Materials. Mouse EGF (receptor grade), insulin (porcine), glucagon, aprotinin, phenylmethylsulphonyl fluoride (PMSF), myelin basic protein (MBP) (bovine brain), dithiothreitol (DTT), wortmannin and $\beta$-glycerophosphate were from Sigma Chemical Co. (St. Louis, Mo., USA). Sodium orthovanadate was from BDH (Poole, Dorset, UK). Leupeptin and pepstatin A were from Peptide Institute (Osaka, Japan). Rapamycin and PD 98059 were from Calbiochem (San Diego, Calif., USA). Hybond-ECL was from Amersham Life Science (Aylesbury, Bucks., UK). Protein kinase A inhibitor (TTYADFIASGRTGRRNAIHD), and 'Crosstide' [16], a substrate for PKB, were synthesized by the Facility for Molecular Biology, University of Newcastle upon Tyne. GSK-3 phosphopeptide substrate [19] was a kind gift from Professor C. Proud (University of Kent, Canterbury, UK). The short S6 substrate peptide (RRRLSSLRA) was from Upstate Biotechnology (Lake Placid, N. Y., USA).

Antibodies. For Western blot analysis, anti-pan ERK, antiERK1 and anti-ERK2 (monoclonal mouse IgG) were from Affiniti Laboratories (Nottingham, Notts, UK), anti-p38 MAP kinase (C-20) was from Santa Cruz Biotechnology (Santa Cruz, Calif., USA) and horse radish peroxidase-coupled antiIgG were from Sigma. For immune complex assays anti-ERK2 (C-14) and p70 $0^{\text {rsk }}$ kinase (C-18) were from Santa Cruz Biotechnology. Antibodies against the pleckstrin homology domain of PKB- $\alpha$ [16] were generously provided by Dr. B. Hemmings (Basel, Switzerland) and antibodies against MAPKAP2 were a kind gift from Dr. D. Alessi (Dundee, UK). Antibodies against GSK-3 isoforms were as described previously [9].

Hepatocyte isolation and culture. Rats were either from the Comparative Biology Centre, University of Newcastle upon Tyne or from Bantin and Kingman, Hull, UK. Hepatocytes were isolated by collagenase perfusion of whole livers of male Wistar rats (170--200 g body weight) fed on standard rat chow ad libitum [2]. The hepatocytes were cultured in 6-well or 24well plates as described previously [2] at a density of 6-$8 \times 10^{4}$ cells $/ \mathrm{cm}^{2}$. The cells were inoculated in Minimum Essential Medium (MEM) supplemented with $5 \%$ (v/v) neonatal calf serum. After cell attachment the medium was replaced with serum-free medium supplemented with $10 \mathrm{nmol} / \mathrm{l}$ dexamethasone and the hepatocytes were cultured for $16 \mathrm{~h}$. Unless indicated otherwise the medium contained $5 \mathrm{mmol} / \mathrm{l}$ glucose.

Immunoprecipitation and kinase assays. Hepatocytes in 6-well plates were incubated in MEM ( $5 \mathrm{mmol} / \mathrm{l}$ glucose) with agonists and washed twice with ice-cold saline before extraction by brief sonication in $700 \mu \mathrm{l} /$ well of buffer containing (mmol/ 1) $100 \mathrm{Tris} / \mathrm{HCl}, 100 \mathrm{KCl}, 2$ EDTA, $25 \mathrm{KF}, 1$ benzamidine, 0.5 $\mathrm{Na}_{3} \mathrm{VO}_{4}, 0.1 \%$ (v/v) Triton X-100, $10 \mu \mathrm{g} / \mathrm{ml}$ leupeptin, $10 \mu \mathrm{g} /$ $\mathrm{ml}$ pepstatin-A, $\mathrm{pH}$ 7.3. Cell extracts were centrifuged for $5 \mathrm{~min}$ at $13000 \mathrm{~g}$. Samples $(150 \mu \mathrm{l})$ of supernatants containing approximately $50 \mu \mathrm{g}$ of protein were incubated with antiERK-2 $(0.4 \mu \mathrm{g})$ or anti-p70 S6 kinase $(0.2 \mu \mathrm{g})$ for $90 \mathrm{~min}$ at $4{ }^{\circ} \mathrm{C}$. Protein A $(2 \mathrm{mg})$ immobilized on Sepharose CL-4B equilibrated at $100 \mathrm{mg} / \mathrm{ml}$ in extraction buffer was added and 
the incubation continued for $1 \mathrm{~h}$ with occasional gentle vortexing. The immobilized immune complexes were recovered by brief centrifugation at $13000 \mathrm{~g}$ and three washes with $200 \mu \mathrm{l}$ aliquots of extraction buffer. Pellets were suspended in $20 \mu \mathrm{l}$ of extraction buffer and ERK-2 or p70 ${ }^{\text {rsk }}$ activity determined using myelin basic protein or short $\mathrm{S} 6$ peptide as substrate, respectively. Assays were for $30 \mathrm{~min}$ at $30^{\circ} \mathrm{C}$ in the presence of $10 \mathrm{mmol} / 1 \mathrm{MgCl}{ }_{2}, 50 \mu \mathrm{mol} / 1\left[\gamma_{-}{ }^{32} \mathrm{P}\right]$ ATP $(3000 \mathrm{cpm} / \mathrm{pmol})$, and either MBP $(0.33 \mathrm{mg} / \mathrm{ml})$ or S6 peptide $(50 \mu \mathrm{mol} / \mathrm{l})$. Radiolabeled peptide products were spotted onto P81 paper following brief centrifugation of immune complexes at $13000 \mathrm{~g}$ and the papers were washed four times in a total of 8 litres of orthophosphoric acid $(180 \mathrm{mmol} / \mathrm{l})$ for $5 \mathrm{~min}$ each wash and dried with a heat lamp. The radioactivity was determined by liquid scintillation counting. Blank values were determined using extraction buffer in place of sample in the reaction mixture. $\mathrm{Ki}$ nase activity is expressed as milliunits per mg protein, where 1 unit corresponds to the incorporation of $1 \mathrm{nmol} / \mathrm{l}$ of phosphate per min. GSK-3 and PKB were assayed by immunoprecipitation using anti-GSK-3 $\alpha / \beta$ mixture or anti-PKB antibodies as described in [9], except that aliquots of cell extract containing $40 \mu \mathrm{g}$ of cell protein were used. MAPKAP-2 was assayed as in [20] following immunoprecipitation with antiMAPKAP-2.

Chromatography of cell extracts on Mono $Q$. Hepatocyte monolayers in 6-well plates were incubated in MEM (5 mmol/1 glucose) with agonists as described in Results. On termination of the incubation monolayers were washed once with ice-cold saline $(150 \mathrm{mmol} / \mathrm{l} \mathrm{NaCl})$. All subsequent steps were performed at $4{ }^{\circ} \mathrm{C}$. Cell extracts for fractionation by FPLC were prepared essentially as previously described [21]. Extraction buffer $(25 \mathrm{mmol} / \mathrm{l} \beta$-glycerophosphate $\mathrm{pH} 7.4,1.5 \mathrm{mmol} / \mathrm{l}$ EGTA, $1 \mathrm{mmol} / \mathrm{l}$ DTT, $1 \mathrm{mmol} / \mathrm{l}$ orthovanadate, $400 \mu \mathrm{mol} / 1 \mathrm{PMSF}$ and $1 \mu \mathrm{g} / \mathrm{ml}$ each of leupeptin, pepstatin A and aprotinin) was added to each well $(800 \mu \mathrm{l})$ and monolayers were immediately sonicated for 1--2 s. Cell extracts from two 6-well plates were pooled and centrifuged at $100000 \mathrm{~g}$ for $60 \mathrm{~min}$. We applied $4 \mathrm{mg}$ of supernatant protein to a Mono Q HR5/5 column (Pharmacia, Uppsala, Sweden) that had been pre-equilibrated with extraction buffer. Fractions $(1 \mathrm{ml})$ were collected during elution with a linear $\mathrm{NaCl}$ gradient $(0--700 \mathrm{mmol} / \mathrm{l})$ in extraction buffer over $40 \mathrm{~min}$ at a flow rate of $1 \mathrm{ml} / \mathrm{min}$.

Assay of MBP kinase. MBP kinase was assayed using myelin basic protein (MBP) as substrate [22]. We incubated $20 \mu \mathrm{l}$ of each Mono Q fraction with $\operatorname{MBP}(0.33 \mathrm{mg} / \mathrm{ml})$ for $20 \mathrm{~min}$ at $30^{\circ} \mathrm{C}$ in a final volume of $35 \mu \mathrm{l}$ containing $50 \mu \mathrm{mol} / \mathrm{l}[\gamma$ $\left.{ }^{32} \mathrm{P}\right]$ ATP $(2500 \mathrm{cpm} / \mathrm{pmol}), 2 \mu \mathrm{mol} / \mathrm{l}$ A-kinase inhibitor, $10 \mathrm{mmol} / \mathrm{l} \mathrm{MgCl}_{2}, 25 \mathrm{mmol} / \mathrm{l} \mathrm{HEPES}, \mathrm{pH}$ 7.4. On termination of the incubation, non-radiolabelled ATP and pyrophosphate were added to each tube to give final concentrations of 10 and $1 \mathrm{mmol} / \mathrm{l}$, respectively, and an aliquot of the reaction mixture was spotted onto P81 phosphocellulose paper. Papers were washed and kinase activity determined as described above.

Western blotting of MAP kinases. Aliquots $(15 \mu \mathrm{l})$ of Mono Q fractions were analysed by SDS-PAGE (10\% polyacrylamide). Proteins were transferred onto nitrocellulose membranes, blocked in $150 \mathrm{mmol} / 1 \mathrm{NaCl}, 0.1 \%$ Tween 20 containing $5 \%$ non-fat powdered milk and exposed for $16 \mathrm{~h}$ at $4{ }^{\circ} \mathrm{C}$ to monoclonal antibodies to MAP kinase (Affiniti Laboratories; anti-pan ERK, anti-ERK1 or anti-ERK2 isotype mouse IgG2a, 1:1000 or Santa Cruz rabbit anti-p38 MAP kinase $1: 2500$ in $150 \mathrm{mmol} / \mathrm{l} \mathrm{NaCl}, 1 \% \mathrm{BSA}, 0.1 \%$ Tween 20 ). After extensive washing in $150 \mathrm{mmol} / \mathrm{l} \mathrm{NaCl}$, membranes were incubated at $37^{\circ} \mathrm{C}$ for $1 \mathrm{~h}$ with horseradish peroxidase-coupled rab- bit anti-mouse or anti-rabbit IgG (Sigma, 1:1000 in $150 \mathrm{mmol} / \mathrm{l}$ $\mathrm{NaCl}, 1 \%$ BSA, $0.1 \%$ Tween 20). Membranes were washed thoroughly in $150 \mathrm{mmol} / \mathrm{l} \mathrm{NaCl}$ and developed with the enhanced chemiluminescent (ECL) method (Amersham International, Amersham, Bucks, UK) followed by brief exposure to ECL X-ray film.

Kinase assays in MBP-containing polyacrylamide gels. Aliquots $(15 \mu \mathrm{l})$ of Mono $\mathrm{Q}$ fractions were boiled in Laemmli sample buffer for $5 \mathrm{~min}$, then electrophoresed in a $10 \%$ SDSPAGE gel containing $0.33 \mathrm{mg} / \mathrm{ml} \mathrm{MBP}$. After fixing the gel with four changes of $20 \%$ propan-2-ol in $50 \mathrm{mmol} / 1$ Tris- $\mathrm{HCl}$ ( $\mathrm{pH} 8.0$ ) for $2 \mathrm{~h}$, SDS was removed by washing the gel in several volumes of $50 \mathrm{mmol} / \mathrm{l}$ Tris- $\mathrm{HCl}(\mathrm{pH} 8.0)$ containing $5 \mathrm{mmol} / \mathrm{l}$ mercaptoethanol. The MBP kinases in the gel were then re-denatured in $6 \mathrm{~mol} / \mathrm{l}$ guanidine $\mathrm{HCl}$ for $2 \mathrm{~h}$ and renatured by washing at least 10 times in $200 \mathrm{ml}$ of $50 \mathrm{mmol} / \mathrm{l}$ Tris- $\mathrm{HCl}(\mathrm{pH}$ 8.0) containing $0.04 \%$ Tween 20 and $2 \mathrm{mmol} / \mathrm{l}$ mercaptoethanol (30 min each wash). After preincubation for $1 \mathrm{~h}$ in $10 \mathrm{ml}$ of $40 \mathrm{mmol} / 1 \mathrm{HEPES}$ ( $\mathrm{pH} 8.0$ ) containing $2 \mathrm{mmol} / \mathrm{l}$ mercaptoethanol and $10 \mathrm{mmol} / \mathrm{l} \mathrm{MgCl}_{2}$, phosphorylation of $\mathrm{MBP}$ was carried out by incubation of the gel at room temperature for $5 \mathrm{~h}$ in $7.5 \mathrm{ml}$ of $40 \mathrm{mmol} / 1$ HEPES ( $\mathrm{pH} 8.0$ ), containing $40 \mu \mathrm{mol} / \mathrm{l}$ $\left[\gamma^{32} \mathrm{P}\right]$ ATP $(550 \mathrm{cpm} / \mathrm{pmol}), 0.5 \mathrm{mmol} / \mathrm{l}$ EGTA, $10 \mathrm{mmol} / \mathrm{l}$ $\mathrm{MgCl}_{2}$ and $2 \mu \mathrm{mol} / 1 \mathrm{~A}$-kinase inhibitor. Excess radiolabelled ATP was removed from the gel by several washes in $5 \%(\mathrm{w} / \mathrm{v})$ trichloroacetic acid containing 1\% sodium pyrophosphate. The gel was dried and MBP kinases visualized by phosphorimaging.

Glycogen synthesis. Glycogen synthesis was determined by incorporation of $\left[\mathrm{U}-{ }^{14} \mathrm{C}\right]$ glucose into glycogen. Hepatocyte monolayers in 24-well plates were incubated for $2 \mathrm{~h}$ or $3 \mathrm{~h}$ in MEM containing $10--25 \mathrm{mmol} / 1\left[\mathrm{U}_{-}{ }^{14} \mathrm{C}\right]$ glucose $(1.5 \mu \mathrm{Ci} / \mathrm{ml})$ and insulin $(0--100 \mathrm{nmol} / \mathrm{l})$ or inhibitors as indicated. Incorporation of ${ }^{14} \mathrm{C}$-label into glycogen was determined by ethanol precipitation as in [2]. Glycogen synthesis is expressed as $\mathrm{nmol} / 1{ }^{14} \mathrm{C}$-glucose incorporated per $\mathrm{mg}$ cell protein.

Assay of glycogen synthase. Glycogen synthase was assayed essentially as described [23]. Hepatocyte monolayers were preincubated in MEM ( $5 \mathrm{mmol} / \mathrm{l}$ glucose) with agonists as described in Results. Incubations were continued for $30 \mathrm{~min}$ without or with $10 \mathrm{nmol} / \mathrm{l}$ insulin. Monolayers were washed with saline and permeabilized with digitonin $(0.05 \mathrm{mg} / \mathrm{ml})$ in buffer containing $62.5 \mathrm{mmol} / \mathrm{l} \mathrm{Tris} / \mathrm{HCl}, 5 \mathrm{mmol} / \mathrm{l} \mathrm{EDTA}, 25 \mathrm{mmol} / \mathrm{l} \mathrm{KF}$, $\mathrm{pH}$ 7.8. After $1 \mathrm{~min}$ an aliquot of $5 \times$ assay buffer (final concentrations $4.6 \mathrm{mmol} / \mathrm{l}\left[{ }^{3} \mathrm{H}\right] \mathrm{UDP}$-glucose $(1.75 \mathrm{Ci} / \mathrm{mol}), 1 \%$ rabbit liver glycogen) was added to each well and incubations were for $20 \mathrm{~min}$ at $30^{\circ} \mathrm{C}$. Synthase $a$ and total synthase were determined in the presence of 0.1 and $10 \mathrm{mmol} / 1$ glucose 6phosphate, respectively. Reactions were terminated by sonication of the cells and spotting aliquots onto a $2 \mathrm{~cm}^{2}$ piece of Whatman ECH $2 \mathrm{R}$ paper. The papers were washed three times in $66 \%(\mathrm{v} / \mathrm{v})$ ethanol and allowed to dry. Radioactivity was determined by liquid scintillation counting. The activities of synthase $a$ and total synthase are expressed as milliunits/mg cell protein, where 1 unit represents incorporation of $1 \mu \mathrm{mol} / \mathrm{l}$ UDP- $\left[{ }^{3} \mathrm{H}\right]$-glucose into glycogen per min.

Statistical analysis. All values given are means \pm SEM for the number of hepatocyte preparations indicated, and statistical analysis was by Student's $t$-test. 

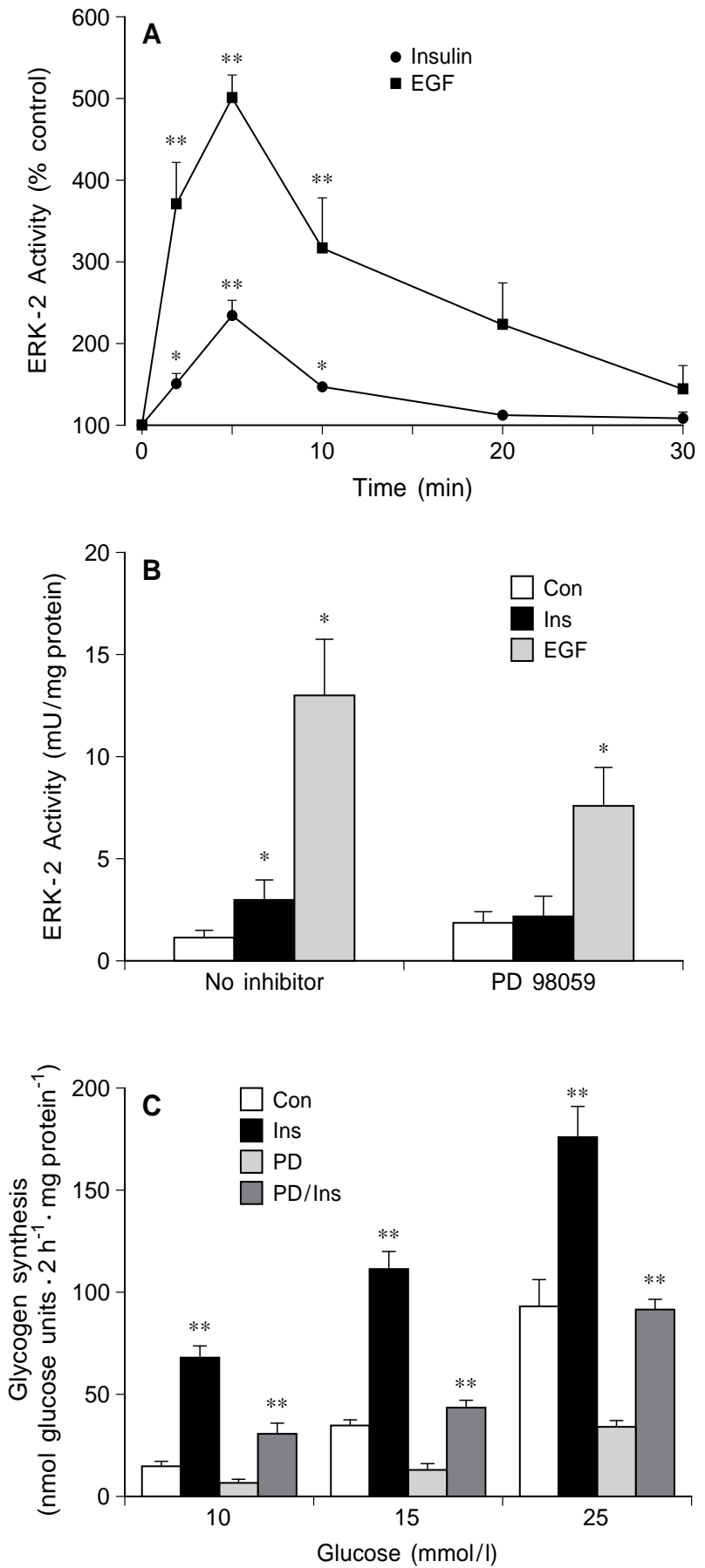

Fig.1 A--C. Effects of the MEK inhibitor PD 98059 on stimulation of ERK-2 and glycogen synthesis by insulin. (A) Hepatocytes were incubated in MEM with $100 \mathrm{nmol} / \mathrm{l}$ insulin or 10 $\mathrm{nmol} / \mathrm{l}$ EGF for 0--30 min and ERK-2 activity was determined as described in the Methods section. (B) Cells were incubated for $60 \mathrm{~min}$ in MEM containing $0.1 \%$ (v/v) DMSO either without or with $50 \mu \mathrm{mol} / 1 \mathrm{PD} 98059$, followed by $5 \mathrm{~min}$ without or with $100 \mathrm{nmol} / \mathrm{l}$ insulin or $10 \mathrm{nmol} / \mathrm{l}$ EGF. ERK-2 activity was then determined as described in the Methods section. (C) Cells were incubated for $2 \mathrm{~h}$ in MEM containing $0.1 \%(\mathrm{v} / \mathrm{v})$ DMSO and $10--25 \mathrm{mmol} / \mathrm{l}\left[\mathrm{U}-{ }^{14} \mathrm{C}\right]$ glucose without or with $10 \mathrm{nmol} / \mathrm{l}$ insulin and $50 \mu \mathrm{mol} / 1 \mathrm{PD} 98059$. Glycogen synthesis was determined from the incorporation of ${ }^{14} \mathrm{C}$-glucose into glycogen. Values are means \pm SEM for $4(\mathrm{~A})$ or $6(\mathrm{~B}, \mathrm{C})$ hepatocyte preparations. $* p<0.05, * * p<0.01$, insulin or EGF vs respective control
Table 1. Lack of effect of PD 98059 on activation of glycogen synthase by insulin

\begin{tabular}{llll}
\hline & \multicolumn{2}{l}{ Glycogen synthase $(\mathrm{mU} / \mathrm{mg}$ protein) } & $\begin{array}{l}\text { Fractional } \\
\text { activity }\end{array}$ \\
\cline { 2 - 3 } & synthase $a$ & total & \\
\hline Control & $0.28 \pm 0.06$ & $1.33 \pm 0.14$ & $0.21 \pm 0.04$ \\
Insulin & $0.42 \pm 0.08^{\mathrm{a}}$ & $1.41 \pm 0.10$ & $0.30 \pm 0.06^{\mathrm{a}}$ \\
$\mathrm{PD}$ & $0.25 \pm 0.05$ & $1.29 \pm 0.07$ & $0.20 \pm 0.04$ \\
$\mathrm{PD}+$ insulin & $0.41 \pm 0.08^{\mathrm{a}}$ & $1.30 \pm 0.11$ & $0.31 \pm 0.06^{\mathrm{a}}$ \\
\hline
\end{tabular}

Hepatocytes were incubated for $60 \mathrm{~min}$ in MEM containing $0.1 \%$ DMSO (v/v) either without or with $50 \mu \mathrm{mol} / 1$ PD 98059. Incubations were then continued for $10 \mathrm{~min}$ without or with $10 \mathrm{nmol} / \mathrm{l}$ insulin. Glycogen synthase activity was determined as described in the Methods section. The fractional activity represents the ratio of synthase a/total activity. Values are means \pm SEM for 4 hepatocyte preparations. ${ }^{a} p<0.05$, insulin vs respective control

\section{Results}

Effects of insulin and EGF on ERK-2 activation and glycogen synthesis. The effects of insulin and EGF on ERK-2 activity are shown in Figure 1. In hepatocytes the activity of ERK-1 determined by in-gel MBP kinase analysis and the immunoreactivity determined by Western blotting was very low in comparison with ERK-2 and could not be accurately determined. Both insulin and EGF caused transient activation of ERK-2 which was maximal at $5 \mathrm{~min}$ and declined thereafter. The stimulation of ERK-2 by insulin was $20--30 \%$ of that elicited by EGF (Fig.1A). The possible involvement of ERK-2 activation in the stimulation of glycogen synthesis and activation of glycogen synthase by insulin was examined using an inhibitor (PD 98059) to prevent MEK activation of ERK-2. At a concentration of $50 \mu \mathrm{mol} / \mathrm{l}$, the inhibitor totally blocked the activation of ERK-2 by insulin but it suppressed the EGF stimulation by only $50 \%$ (Fig. 1B). These findings are similar to results on other cell types which demonstrate complete inhibition by PD 98059 of low levels of activation of ERK-2, but only partial counteraction by agonists which cause large stimulation [11, 24]. PD 98059 inhibited the incorporation of $10--25 \mathrm{mmol} / \mathrm{l}\left[\mathrm{U}_{-}{ }^{14} \mathrm{C}\right]$-glucose into glycogen in both the absence of insulin (57, 66 and $59 \%)$ and in the presence of insulin $(55,62$ and $44 \%$ of respective controls at 10,15 and $25 \mathrm{mmol} / 1$ glucose). The percentage increase in glycogen synthesis by insulin was similar in the absence and presence of inhibitor $(10 \mathrm{mmol} / \mathrm{l}$ glucose, 503 vs 527 ; $15 \mathrm{mmol} / \mathrm{l}$ glucose, 337 vs $373 ; 25 \mathrm{mmol} / 1$ glucose, 204 vs $277 \%$ stimulation by insulin, absence vs presence of PD, Fig.1C). PD 98059 did not affect either the basal activity of glycogen synthase $a$ or the stimulation by insulin (Table 1), suggesting that activation of ERK-2 is not essential for either activation of glycogen synthase or stimulation of glycogen synthesis by insulin. 

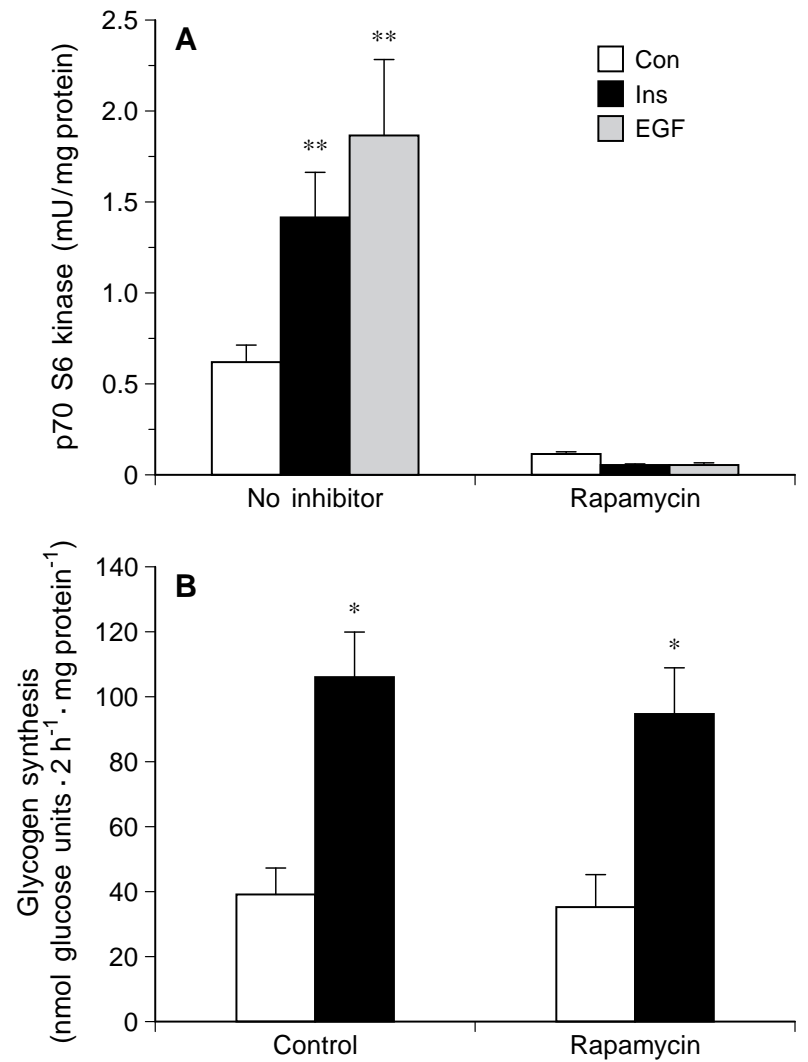

Fig. $2 \mathrm{~A}, \mathbf{B}$. Inhibition of p $70^{\text {rsk }}$ does not prevent stimulation of glycogen synthesis by insulin. (A) Hepatocytes were incubated for $15 \mathrm{~min}$ without or with $100 \mathrm{nmol} / \mathrm{l}$ rapamycin, followed by $5 \mathrm{~min}$ without or with $100 \mathrm{nmol} / \mathrm{l}$ insulin or $10 \mathrm{nmol} / \mathrm{l} \mathrm{EGF}$. p $70^{\text {rsk }}$ activity was determined as described in the Methods section. (B) Cells were incubated for $2 \mathrm{~h}$ in MEM containing $15 \mathrm{mmol} / \mathrm{l}\left[\mathrm{U}_{-}{ }^{14} \mathrm{C}\right.$ ] glucose in the absence or presence of 10 $\mathrm{nmol} / \mathrm{l}$ insulin or $100 \mathrm{nmol} / \mathrm{l}$ rapamycin. Glycogen synthesis was determined from the incorporation of ${ }^{14} \mathrm{C}$-glucose into glycogen. Values are means \pm SEM for 4 hepatocyte preparations $* p<0.05, * * p<0.005$, insulin or EGF vs respective control

Effects of insulin and EGF on $p 70^{r s k}$ activation. An alternative pathway that may lead to activation of glycogen synthase and stimulation of glycogen synthesis involves activation of PI 3-kinase leading to activation of $\mathrm{p} 70^{\mathrm{rsk}}[25,26]$. Rapamycin, an inhibitor of $\mathrm{p} 70^{\text {rsk }}$, has been shown to partially counteract activation of glycogen synthase or stimulation of glycogen synthesis by insulin in human myoblasts [9], 3T3-L1 adipocytes [10] and rat diaphragm [11], and wortmannin an inhibitor of PI-3 kinase, also counteracts activation of glycogen synthase by insulin in these cells $[9,10]$. EGF and insulin activated $\mathrm{p} 70^{\text {rsk }}$ in hepatocytes by 3 -fold and 2.3-fold, respectively (Fig.2A). Rapamycin lowered the basal activity of $\mathrm{p} 70^{\text {rsk }}$ by $80 \%$ and totally abolished the stimulation by both insulin and EGF. However, rapamycin neither affected the basal rate of glycogen synthesis nor the stimulation by insulin (Fig. 2B) indicating that activation of $\mathrm{p} 70^{\mathrm{rsk}}$ is not essential for the stimulation of glycogen synthesis by insulin. Rapamycin also did not counter-
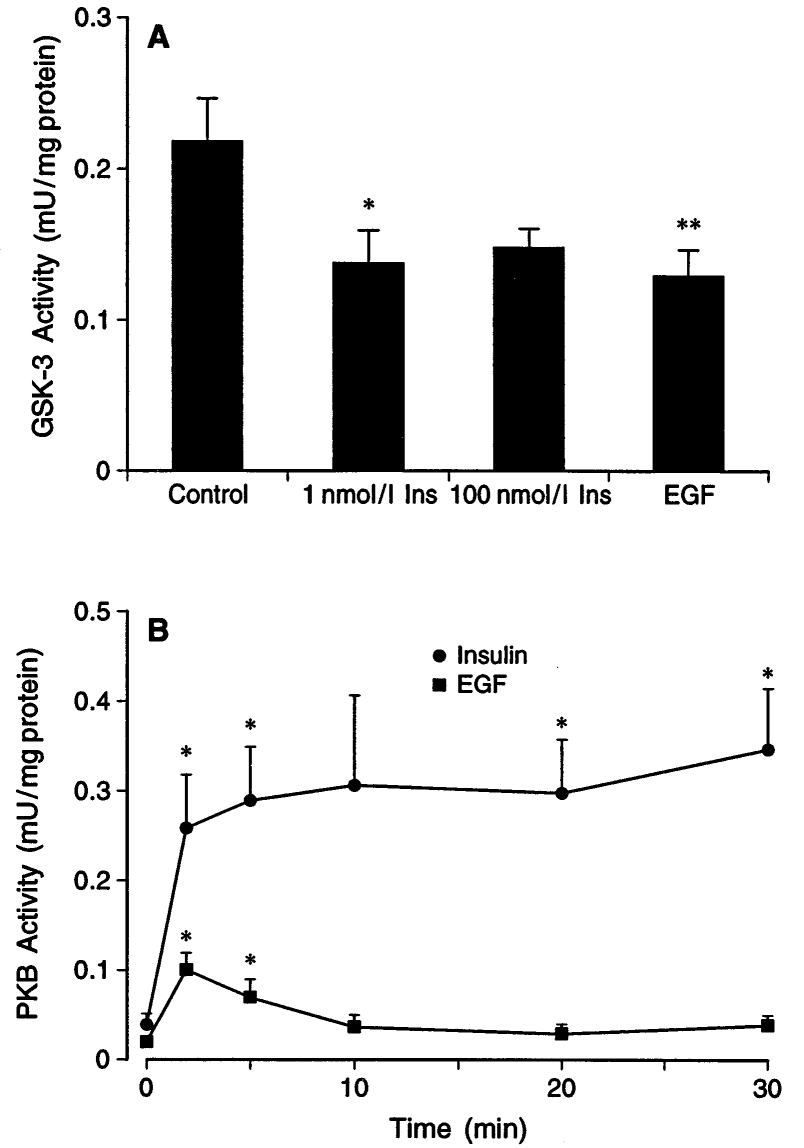

Fig.3 A, B. Effects of insulin and EGF on GSK-3 and PKB activity. (A) GSK-3 activity was determined after incubation without or with insulin (1 or $100 \mathrm{nmol} / \mathrm{l})$ or EGF (10 nmol/l) for 5 min. (B) $\mathrm{PKB}$ activity was determined after incubation with insulin $(100 \mathrm{nmol} / \mathrm{l})$ or EGF $(10 \mathrm{nmol} / \mathrm{l})$ for $0--60 \mathrm{~min}$. Values are means \pm SEM for 3 (A) or 4 (B) hepatocyte preparations. ${ }^{*} p<0.05, * * p<0.005$, insulin or EGF vs respective control

act the stimulation of glycogen synthase by insulin either in the absence of other inhibitors (control, $0.49 \pm 0.06$; insulin, $0.58 \pm 0.09^{\mathrm{a}}$ : rapamycin, $0.48 \pm$ 0.07 ; rapamycin + insulin, $0.61 \pm 0.10^{\mathrm{a}}$ ) or in the additional presence of $50 \mu \mathrm{mol} / \mathrm{l} \mathrm{PD} 98059$ (PD, $0.51 \pm$ $0.09 ; \quad \mathrm{PD}+$ insulin, $0.64 \pm 0.10^{\mathrm{a}}$ : $\mathrm{PD}+$ rapamycin, $0.53 \pm 0.08 ; \quad \mathrm{PD}+$ rapamycin + insulin, $\quad 0.65 \pm 0.10^{\mathrm{a}}$ $\mathrm{mU} / \mathrm{mg}$ protein, means $\pm \mathrm{SEM}, n=6,{ }^{\mathrm{a}} p<0.05$ insulin vs respective control). In additional experiments performed at $15 \mathrm{mmol} / \mathrm{l}$ glucose a similar lack of effect of these inhibitors on insulin-stimulated glycogen synthase activity was observed (results not shown).

Effects of insulin and EGF on GSK-3 and PKB activity. The effects of insulin and EGF on GSK-3 and PKB in hepatocytes are shown in Figure 3. Insulin has been shown to inactivate GSK-3 in adipocytes [7], human myoblasts [9], Chinese hamster ovary (CHO) cells [19] and L6 myotubes [27]. Figure 3A shows that insulin $(1,100 \mathrm{nmol} / \mathrm{l})$ and EGF (10 


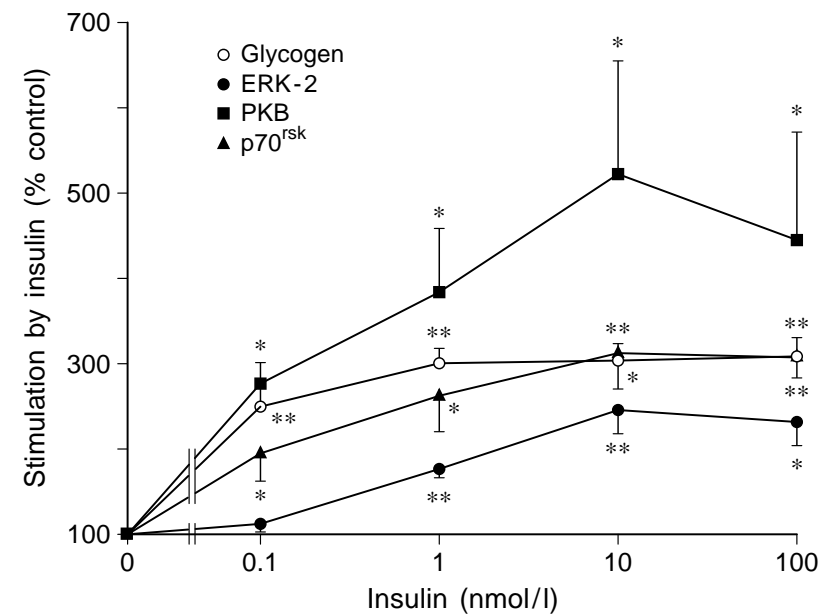

Fig. 4. Sensitivity of glycogen synthesis and insulin-stimulated kinases to insulin. ERK-2, p70 ${ }^{\text {rsk }}$ and PKB were determined after incubation of hepatocytes without or with insulin (0.1--100 $\mathrm{nmol} / \mathrm{l}$ ) for $5 \mathrm{~min}$. In parallel experiments hepatocytes were incubated without or with insulin $(0.1--100 \mathrm{nmol} / \mathrm{l})$ for $2 \mathrm{~h}$ with $15 \mathrm{mmol} / \mathrm{l}\left[\mathrm{U}-{ }^{14} \mathrm{C}\right]$ glucose for determination of glycogen synthesis. Values are means \pm SEM for 4 (p70 ${ }^{\text {rsk }}$, PKB), 5 (ERK2) or 8 (glycogen) hepatocyte preparations. Basal activities were ERK-2, $0.66 \pm 0.14 ;$ p70 ${ }^{\text {rsk }}, 0.52 \pm 0.14 ;$ PKB, $0.044 \pm$ $0.015 \mathrm{mU} / \mathrm{mg}$ protein and basal glycogen synthesis $37.3 \pm 7.3$ $\mathrm{nmol} / \mathrm{l}$ glucose units incorporated into glycogen $/ 2 \mathrm{~h}$ per $\mathrm{mg}$ protein. $* p<0.05, * * p<0.005$ insulin vs respective control

nmol/l) cause a similar inactivation (40\%) of GSK-3 in hepatocytes. Activation of PKB by insulin has been reported in myoblasts [9] and L6 cells [27, 28]. Both insulin and EGF activated PKB in hepatocytes (Fig.3B). Unlike the activation of ERK-2 (Fig.1) and $\mathrm{p} 70^{\text {rsk }}$ (Fig. 2), insulin (100 nmol/l) caused a greater activation of PKB than did EGF $(10 \mathrm{nmol} / \mathrm{l})$. The insulin activation was sustained for $30 \mathrm{~min}$. Figure 4 shows the effects of varying [insulin] on glycogen synthesis and activation of ERK-2, p70 ${ }^{\text {rsk }}$ and PKB. At $0.1 \mathrm{nmol} / 1$ insulin, there was significant stimulation of glycogen synthesis, and of PKB and $\mathrm{p} 70^{\text {rsk }}$ but not of ERK-2, which was activated by insulin only at concentrations $1 \mathrm{nmol} / 1$ or more, suggesting that activation of ERK-2 is less sensitive to insulin than stimulation of glycogen synthesis.

Resolution of MBP kinases from insulin or EGF treated cells by Mono $Q$. Since ERK-2 and p70 ${ }^{\text {rsk }}$ are apparently not involved in the stimulation of glycogen synthesis by insulin we looked for protein kinases that are activated by insulin but not by EGF by fractionation of extracts of insulin-treated or EGF-treated hepatocytes on Mono Q and screening fractions for MBP kinase activity. In hepatocytes treated with EGF (10 nmol/l for $5 \mathrm{~min}$ ) a single peak (peak 1) of MBP phosphorylating activity eluted at $200 \mathrm{mmol} / \mathrm{l}$ $\mathrm{NaCl}$ from Mono Q (Fig. 5A). This represents an 11fold increase in peak height activity with respect to control hepatocytes (control, $4.2 \pm 0.6$; EGF, $48.0 \pm$
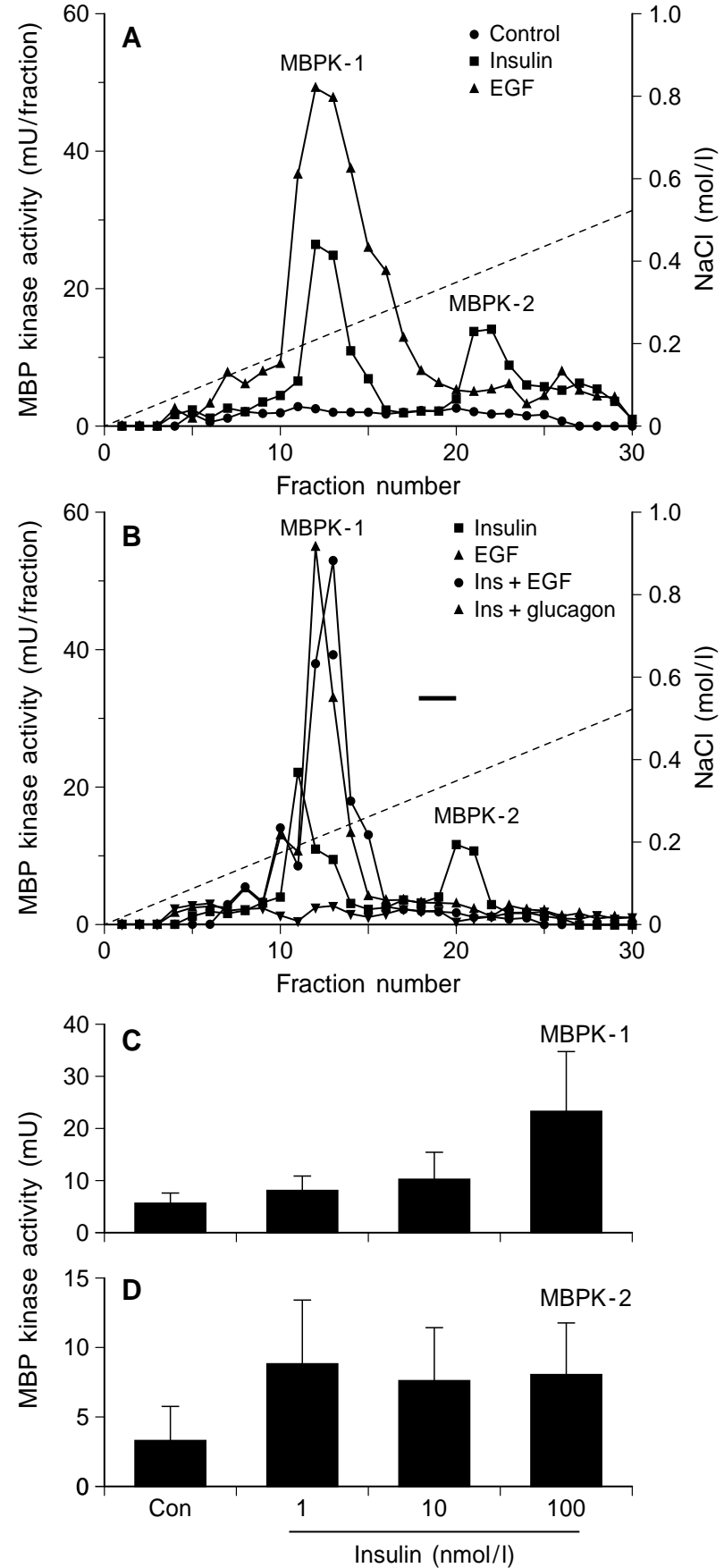

Fig. 5. Resolution of MBP kinase activity from insulin-treated and EGF-treated hepatocytes by chromatography on Mono Q. Cells were incubated with the agonists shown and hepatocytes were extracted as described in the Methods section and aliquots containing $4 \mathrm{mg}$ protein were fractionated on Mono Q. MBP kinase activity is expressed as $\mathrm{mU} /$ fraction. (A) Cells were incubated without or with insulin $(100 \mathrm{nmol} / \mathrm{l})$ or EGF $(10 \mathrm{nmol} / \mathrm{l})$ for $5 \mathrm{~min}$. (B) Cells were incubated with insulin $(100 \mathrm{nmol} / \mathrm{l})$ for $5 \mathrm{~min}$ following no pretreatment or pretreatment for $5 \mathrm{~min}$ with either $10 \mathrm{nmol} / \mathrm{l} \mathrm{EGF}$ or $100 \mathrm{nmol} / \mathrm{l}$ glucagon. The horizontal bar indicates those fractions which contain p38 MAP kinase as detected by Western blotting. The effects of insulin concentration on the activation of MBP kinase peak 1 (C) and MBP kinase peak 2 (D) are shown. Values represent the intergrated sum of MBP kinase activity in each peak per $\mathrm{mg}$ of cell protein loaded and are means \pm SEM for 3 hepatocyte preparations 

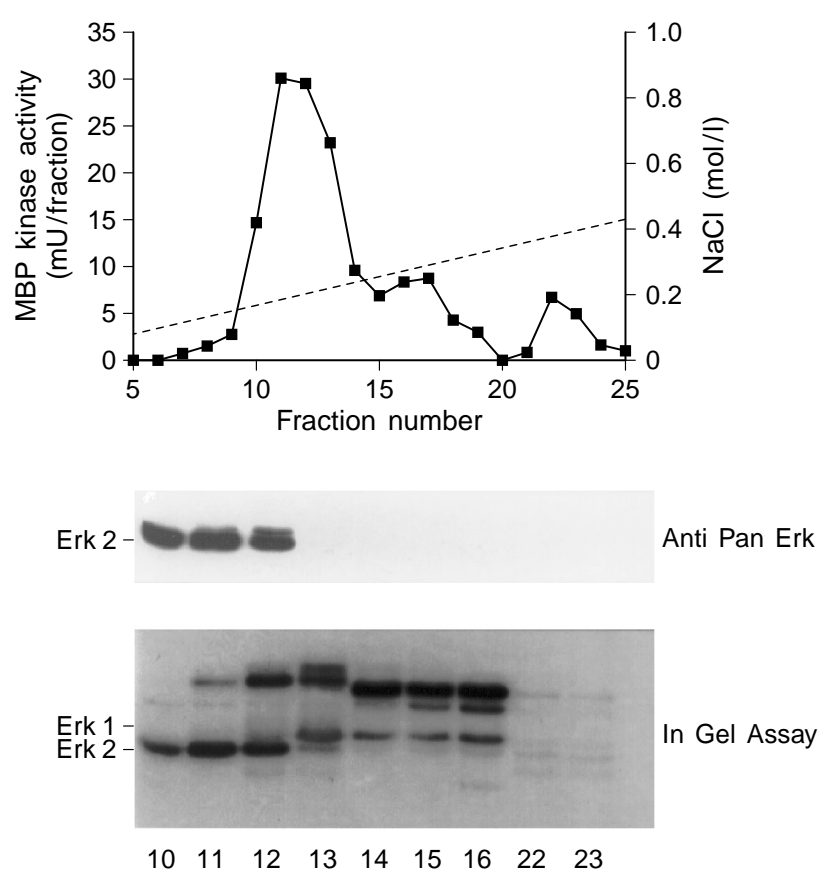

Fig. 6. Identification of ERK1 and ERK2 in hepatocytes. Aliquots $(15 \mu \mathrm{l})$ of Mono $\mathrm{Q}$ fractions corresponding to MBP kinase peak 1 or peak 2 from cells treated with insulin (100 $\mathrm{nmol} / \mathrm{l}, 5 \mathrm{~min}$ ) were separated by SDS-PAGE in gels without or with $0.5 \mathrm{mg} / \mathrm{ml} \mathrm{MBP}$. For Western blotting, fractions were immunoblotted using anti-pan ERK. In gel MBP kinase assays were performed as described in the Methods section. The positions of ERK-1 and ERK-2 are indicated

$4.2 \mathrm{mU} /$ fraction, $n=4)$. In contrast, in extracts of hepatocytes incubated with insulin $(100 \mathrm{nmol} / \mathrm{l}$ for 5 min) two peaks of MBP kinase activity were resolved, one eluting at $200 \mathrm{mmol} / \mathrm{l} \mathrm{NaCl}$ (peak 1) and a second at $400 \mathrm{mmol} / \mathrm{l} \mathrm{NaCl}$ (peak 2) (Fig.5A), representing 5-fold and 2.5-fold increases in the peak height activity, respectively (peak 1 control, $4.6 \pm 0.7$; insulin, 21.4 \pm 2.7 : peak 2 control, $4.0 \pm 0.6$; insulin, $9.9 \pm 1.4 \mathrm{mU} /$ fraction, $n=7$ ). The MBP kinases in peak 1 and peak 2 from Mono Q fractionation were characterized using in situ kinase assays in gels containing MBP and with antibodies specific to MAP kinases (Fig. 6). When Mono Q fractions from insulin-treated cells were fractionated in SDS-PAGE gels containing MBP (in-gel assay) they showed a 42 $\mathrm{kDa}$ (ERK2) band corresponding to peak 1 (fractions 10--13) and a minor band at $44 \mathrm{kDa}$ (ERK1) eluting at higher salt concentrations (fractions 13--16). In the same fractions there are additional MBP kinases of 55--65 kDa which co-elute with ERK1. However in-gel assays of whole cell hepatocyte extracts suggested that these additional MBP kinases were not activated by insulin (result not shown). In Mono Q fractions corresponding to MBP kinase peak 2, there was no detectable MBP kinase activity using this technique, suggesting that this peak is not an activated form of ERK1 or ERK2 and that the kinase in- volved does not re-nature sufficiently under the conditions used.

Immunoblotting of peak 1 from insulin-treated hepatocytes with anti-pan ERK, which is reported to react with MAP kinases of 54 and $85 \mathrm{kDa}$ in addition to ERK1 and ERK2 (Affiniti Laboratories), identified one major protein of approximately $42 \mathrm{kDa}$ (fractions 10--12). Fractions 11 and 12 show a small band shift of the $42 \mathrm{kDa}$ protein indicating the presence of activated ERK 2. Since ERK 1 could not be detected using anti-pan ERK, it is possible that this antibody is not immunoreactive to hepatic ERK 1, or the amount of ERK-1 is below detectable limits. Similar to insulin-treated cells, immunoblotting of peak 1 from EGF-treated hepatocytes identified the presence of activated ERK2 (result not shown). Peak 2 from insulin-treated cells showed no immunoreactivity further indicating that it does not contain activated ERK2 (Fig. 6). The Mono Q fractions which contain immunoreactive p38 MAP kinase (the HOG1 homologue) are shown in Figure 5B.

Counteraction of insulin stimulation of MBP kinase peak 2 by EGF and glucagon. Since EGF counteracts the stimulation of glycogen synthesis by insulin [17, 18], we determined the combined effects of insulin and EGF on MBP kinases peak 1 and peak 2. In the combined presence of insulin and EGF, the activation of peak 1 was similar to that observed with EGF alone, while the activation of peak 2 was abolished (Fig. 5B). Transforming growth factor $\alpha$, which like EGF counteracts the stimulation of glycogen synthesis by insulin in hepatocytes [6], also counteracted activation of MBP kinase peak 2 by insulin $(n=2$, results not shown). Pre-incubation with $100 \mathrm{nmol} / \mathrm{l}$ glucagon for $5 \mathrm{~min}$ before incubation with insulin for 5 min counteracted the stimulation of both peak 1 and peak 2 by insulin (Fig. 5B), suggesting inhibition by cAMP upstream of ERK-2 and peak 2 . The sensitivity to insulin of activation of peaks 1 and 2 is shown in Figure 5C and D. Peak 2, but not peak 1, was maximally activated by $1 \mathrm{nmol} / \mathrm{l}$ insulin and not further activated by higher concentrations of insulin. This is similar to the effects of insulin on glycogen synthesis (Fig.4) and is consistent with a possible involvement of peak 2 in the stimulation of glycogen synthesis.

Effect of kinase inhibitors on the stimulation of $M B P$ kinases by insulin. Figure 7 shows the effects of inhibitors of phosphatidylinositol 3'-kinase (PI-3) kinase (wortmannin), MEK (PD 98059) and p70 ${ }^{\text {rsk }}$ (rapamycin) on the stimulation of MBP kinases peak 1 and peak 2 by insulin. Both PD 98059 and wortmannin counteracted the stimulation of peak 1 by insulin whereas rapamycin caused only a small inhibition (Fig. 7A). The stimulation of peak 2 was counteracted by wortmannin but not by PD 98059 or rapamycin (Fig. 7B). LY294002 (100 $\mu \mathrm{mol} / \mathrm{l})$, a specific inhibitor 

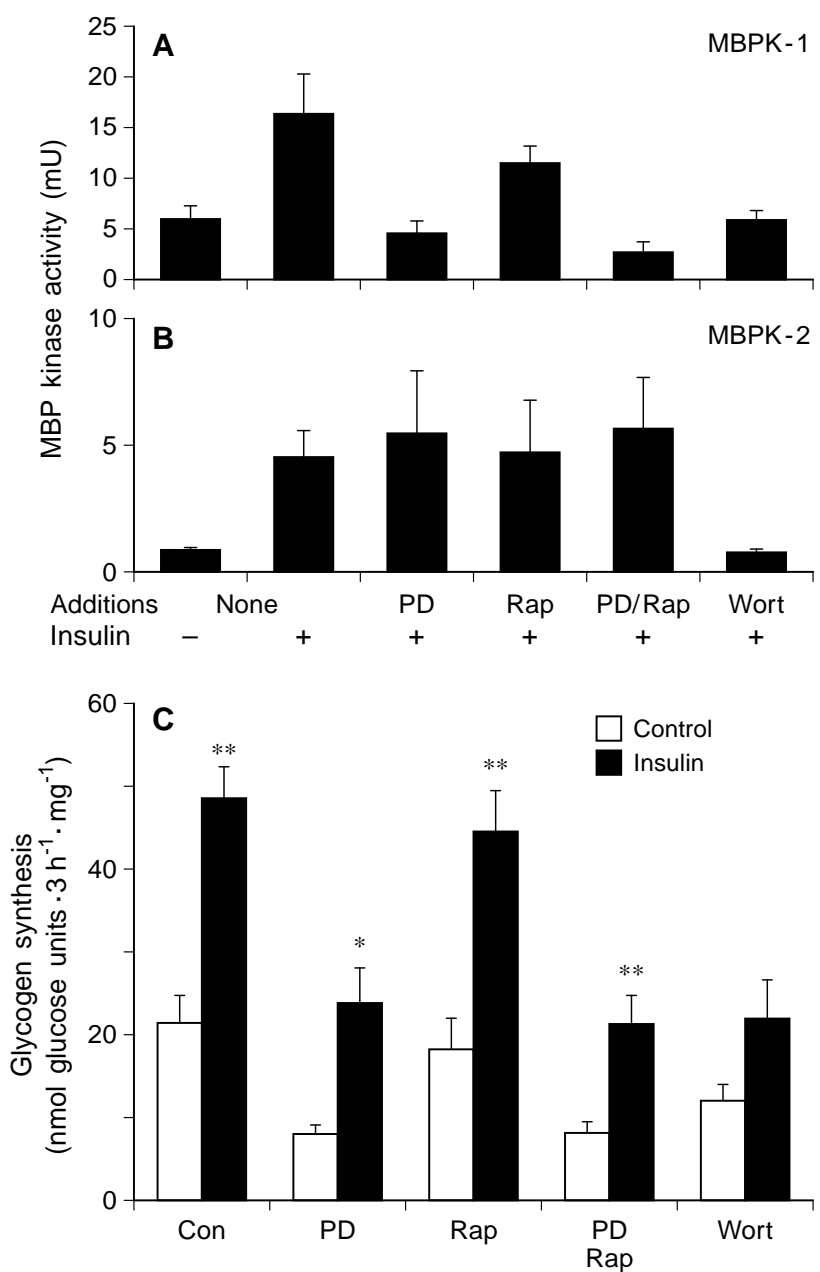

Fig.7A--C. Effect of kinase inhibitors on the stimulation of MBP kinases and glycogen synthesis by insulin. Hepatocytes were incubated in MEM ( $5 \mathrm{mmol} / 1$ glucose) containing $0.1 \%$ DMSO (v/v) without or with inhibitors: $50 \mu \mathrm{mol} / 1$ PD 98059 $(60 \mathrm{~min}), 100 \mathrm{nmol} / 1 \mathrm{rapamycin}(30 \mathrm{~min})$ or $100 \mathrm{nmol} / \mathrm{l}$ wortmannin (30 $\mathrm{min})$ as indicated, and then incubated for a further 5 min with $100 \mathrm{nmol} / \mathrm{l}$ insulin. FPLC fractionation for determination of MBP kinase peak 1 (A) and MBP kinase peak 2 (B) was as described in Figure 5. Values represent the intergrated sum of MBP kinase activity in each peak per mg of cell protein loaded and are means \pm SEM for 3 hepatocyte preparations. (C) Cells were incubated for $3 \mathrm{~h}$ in MEM containing $15 \mathrm{mmol} / \mathrm{l}$ $\left[\mathrm{U}-{ }^{14} \mathrm{C}\right]$ glucose in the absence or presence of insulin $(10$ $\mathrm{nmol} / \mathrm{l}$ ) and the concentrations of inhibitors as in (A). Hepatocytes were extracted and glycogen synthesis determined from the incorporation of ${ }^{14} \mathrm{C}$-glucose into glycogen. Values are means \pm SEM for 6 hepatocyte preparations. $* p<0.05$, ** $p<$ 0.005 , insulin vs respective control

of PI-3 kinase also inhibited the activation of both peak 1 and peak 2 by insulin (results not shown). In the same experiments PD 98059 suppressed both the basal and the insulin-stimulated rate of glycogen synthesis, without counteracting the fold-stimulation by insulin, whereas rapamycin had no effect on either the basal or the insulin-stimulated rate in both the absence and the presence of PD 98059 (Fig. 7C). These results suggest that the activation of peak 2 by insulin

is dependent on PI-3 kinase but not on MEK or $\mathrm{p} 70^{\text {rsk }}$ activity, whereas activation peak 1 is dependent on both PI-3 kinase and MEK. The stimulation of glycogen synthesis by insulin in the presence of both rapamycin and PD 98059 is consistent with a possible involvement of peak 2 but not peak 1 in insulin action.

\section{Discussion}

We demonstrate in this study that insulin causes inactivation of GSK-3 and activation of ERK-2, p70 ${ }^{\text {rsk }}$, $\mathrm{PKB}$ and an as yet unidentified kinase that phosphorylates MBP and elutes at $\sim 400 \mathrm{mmol} / \mathrm{l}$ salt on Mono Q (peak 2). EGF causes a similar inactivation of GSK-3 as insulin, but a greater activation of ERK-2 and p70 ${ }^{\text {rsk }}$ and a smaller activation of PKB than insulin. Unlike insulin, it does not activate peak 2.

The studies using inhibitors which block the activation of $\mathrm{p} 70^{\text {rsk }}$ and ERK-2 by insulin rule out a major involvement of both these kinases in the stimulation of glycogen synthesis by insulin in hepatocytes. Neither rapamycin, which totally abolished the stimulation of p70 ${ }^{\text {rsk }}$ by insulin, nor PD 90859, which blocked the stimulation of ERK-2 by insulin prevented the stimulation of glycogen synthesis or activation of glycogen synthase by insulin. PD 98059 inhibited glycogen synthesis (but not glycogen synthase) in both the absence and presence of insulin, but did not block the stimulation by insulin. This inhibition of glycogen synthesis was not associated with a lowering of cellular ATP or with leakage of lactate dehydrogenase (not shown). Since it was not associated with inactivation of glycogen synthase this effect is most likely due to glucuronidation of this compound, since compounds that are metabolized by glucuronidation can cause depletion of hepatic glycogen through consumption of UDP-glucose [29]. Regardless of the mechanism by which PD 98059 inhibits glycogen synthesis, the lack of effect of this inhibitor on activation of glycogen synthase by insulin eliminates an involvement of ERK-2 in the mechanism by which insulin activates this enzyme. A salient point that emerges from the present study is that stimulation of ERK-2 is less sensitive to insulin concentration than the other metabolic effects determined. Thus activation of ERK-2 by insulin, in addition to being smaller in magnitude than activation by EGF, also showed a lower sensitivity to insulin than the metabolic effects of insulin.

Previous studies using rapamycin have implicated involvement of $\mathrm{p} 70^{\text {rsk }}$ in the control of glycogen synthesis by insulin in human myoblasts [9], 3T3 cells [10] and isolated rat diaphragm [11], though not in freshly isolated adipocytes [7]. The lack of involvement of $\mathrm{p} 70^{\text {rsk }}$ in the stimulation of glycogen synthesis by insulin in hepatocytes is evidence for tissue dif- 
ferences in insulin-signalling pathways between the major physiological targets of insulin. Indeed, the regulation of $\mathrm{p} 70^{\text {rsk }}$ by growth factors appears to be subject to tissue specificity since, unlike in hepatocytes, EGF does not activate $\mathrm{p} 70^{\text {rsk }}$ in diaphragm [11].

Inactivation of GSK-3 by insulin has been demonstrated in adipocytes [7], human myoblasts [9], $\mathrm{CHO}$ cells [19], and L6 myotubes [27]. The activation of glycogen synthase by insulin results from dephosphorylation of sites $(3 a+3 b+3 c)$ and $(2 a+2 b)$ [30]. Sites $3 \mathrm{a}, 3 \mathrm{~b}$ and $3 \mathrm{c}$ are phosphorylated by GSK-3. Overexpression of either wildtype GSK-3 or a mutant with increased activity in the 293 cell line results in suppression of endogenous glycogen synthase, suggesting that activation of GSK-3 contributes to inactivation of glycogen synthase in the intact cell [31]. An interesting finding from the present study is that both insulin, which stimulates glycogen synthesis, and EGF, which counteracts the stimulation by insulin, cause a similar inactivation of GSK-3. Taken together, these observations suggest that inactivation of GSK-3 is itself insufficient to account for the activation of glycogen synthesis by insulin, and/or that EGF counteracts the action of insulin by a mechanism that is independent of GSK-3, possibly involving other counterregulatory mechanisms, such as activation of phospholipase $\mathrm{C}$ [32] with consequent increases in diacylglycerol or calcium, which inhibit glycogen synthesis. It is noteworthy, however that these experiments on the effects of EGF on GSK-3 were performed at a cell density at which EGF blocks the stimulation of glycogen synthesis by insulin but has no effect on the basal rate [18] thus an interaction with insulin-signalling is therefore more plausible. Since both insulin and EGF activated PKB, the present results are consistent with a role for PKB in the phosphorylation and inactivation of GSK-3 in liver. In contrast to the activation of ERK-2 and p70 $0^{\text {rsk }}$ the activation of PKB by insulin is larger than by EGF. In addition the activation of PKB by EGF peaks at 2 min and declines to basal levels by 10 min whereas activation by insulin peaks at $2--5 \mathrm{~min}$ and is sustained for at least $30 \mathrm{~min}$. Therefore, the larger and sustained activation of PKB by insulin compared with EGF suggests that $\mathrm{PKB}$ is a possible candidate in mediating the stimulation of glycogen synthesis by insulin.

MBP kinase (peak 2), which is activated by insulin but not by EGF is of particular interest in the context of the metabolic effects of insulin. To our knowledge this is the first report of activation of a protein kinase by insulin that is not activated by EGF in the same experimental system. Two lines of evidence suggest that this kinase is a potential candidate in the stimulation of glycogen synthesis by insulin. First, the dose-response to insulin for activation of peak 2 is similar to the stimulation of glycogen synthesis by insulin. This contrasts with the sensitivity to insulin of peak 1 or ERK-2. Secondly, there is parallelism between the stimulation of glycogen synthesis and the activation of MBP kinase peak 2 by insulin. The activation of peak 2 by insulin is blocked by both EGF and transforming growth factor $\alpha$, which counteract the stimulation of glycogen synthesis by insulin [6, 17], and also by glucagon and wortmannin, both of which counteract the stimulation of glycogen synthesis. In the presence of either rapamycin, PD 98059 or a combination of both inhibitors, the fold-stimulation by insulin of either glycogen synthesis, glycogen synthase or MBP kinase peak 2 was not inhibited. This suggests that inactivation of GSK-3 by either $\mathrm{p} 70^{\mathrm{rsk}}$ or $\mathrm{p} 90^{\text {rsk }}$ is not responsible for activation of glycogen synthase by insulin in hepatocytes but does not exclude a role for MBP kinase peak 2. A key question is whether peak 2 is a previously reported protein kinase or a novel enzyme. We have excluded the possibility that peak 2 is an activated form of ERK1 or ERK2 or that peak 2 is an isoform of PKB, since following fractionation of extracts of control or insulintreated hepatocytes on Mono Q, MBP kinase peak 2 does not co-elute with insulin-stimulated kinase activity assayed with either "Crosstide" " or RPRAATF [33] as substrate (not shown). We have excluded the posibility that peak 2 may be p38 MAP kinase [34] since Mono $\mathrm{Q}$ fractions containing immunoreactive p38 MAP kinase elute before the fractions containing peak 2 activity. In addition MAPKAP-2, a physiological substrate of p38 MAP kinase, was not activated by insulin in hepatocytes when assayed by immunoprecipitation (M. Peak and R. Halse, unpublished results). Peak 2 was found to be very unstable. It rapidly loses activity on storage and during gel filtration and activity could not be recovered following SDS-fractionation and in-gel assay, which makes its characterization difficult.

Glycogen synthesis in hepatocytes is stimulated by cell swelling induced by either amino acids or by hypotonic media [35]. Insulin increases cell volume in hepatocytes through an increase in cellular $\mathrm{K}^{+}$plus $\mathrm{Na}^{+}$content and this increase in cell volume is an essential component of the mechanism by which insulin stimulates glycogen synthesis [36, 37]. It is therefore of interest to compare the present findings with those of a recent study on the activation of protein kinases by cell swelling in hepatocytes [38]. Cell swelling caused activation of PI-3 kinase and of $\mathrm{p} 70^{\text {rsk }}$, but not ERK-2. However, while wortmannin partially blocked the stimulation of glycogen synthase by cell swelling, rapamycin was without effect indicating lack of involvement in $\mathrm{p} 70^{\text {rsk }}$ in the stimulation of glycogen synthesis by cell swelling. The present study also shows counteraction by wortmannin of the stimulation of glycogen synthesis by insulin. Thus ERK-2 and $\mathrm{p} 70^{\mathrm{rsk}}$ are not involved in the stimulation of glycogen synthesis by either insulin or cell swelling, 
whereas a wortmannin-sensitive mechanism is involved in both processes. These similarities in the involvement of protein kinases in the stimulation of glycogen synthesis by cell swelling [38] and insulin (present study) are consistent with the hypothesis that cell swelling is a component of the mechanism by which insulin stimulates glycogen synthesis in the liver [36].

Acknowledgements. This work was performed in the MRC/ BDA Diabetes Research Centre and was supported by grants from the British Diabetic Association and the Medical Research Council, UK. We thank Dr. Brian Hemmings (Basel) for the gift of antibodies to protein kinase $\mathrm{B}$, and Dr. Jackie Vandenheede (Leuven) for providing antibodies to GSK-3.

\section{References}

1. Stalmans W, Bollen M, Mvumbi L (1987) Control of glycogen synthesis in health and disease. Diabet/Metab Rev 3: 127--161

2. Agius L, Peak M, Alberti KGMM (1990) Regulation of glycogen synthesis from glucose and gluconeogenic precursors by insulin in periportal and perivenous rat hepatocytes. Biochem J 266: 91--102

3. Agius L, Tosh D, Peak M (1993) The contribution of pyruvate cycling to loss of $[6--3 \mathrm{H}]$ glucose during conversion of glucose to glycogen in hepatocytes: effects of insulin, glucose and acinar origin of hepatocytes. Biochem J 289: 255--262

4. Tosh D, Beresford GW, Agius L (1994) Glycogen synthesis from glucose by direct and indirect pathways in hepatocyte cultures from different nutritional states. Biochim Biophys Acta 1224: 205--212

5. Van de Werve G, Sestoft L, Folke M, Kristensen LO (1984) The onset of liver glycogen synthesis in fasted-refed rats. Effects of streptozocin diabetes and of peripheral insulin replacement. Diabetes 33: 944--949

6. Peak M, Agius L (1992) Transforming growth factor alpha inhibits glycogen synthesis and counteracts the stimulation by insulin in hepatocytes. Biochem Biophys Res Commun 183: 560--565

7. Moule SK, Edgell NJ, Welsh GI et al. (1995) Multiple signalling pathways involved in the stimulation of fatty acid and glycogen synthesis by insulin in rat epididymal fat cells. Biochem J 311: 595--601

8. Sakaue J, Hara K, Noguchi T (1995) Ras-independent and wortmannin-sensitive activation of glycogen synthase by insulin in Chinese hamster ovary cells. J Biol Chem 270: 11304--11309

9. Hurel SJ, Rochford JJ, Borthwick AC et al. (1996) Insulin action in cultured human myoblasts: contribution of different signalling pathways to regulation of glycogen synthesis. Biochem J 320: 871--877

10. Shepherd PR, Nave <' BT, Siddle K (1995) Insulin stimulation of glycogen synthesis and glycogen synthase activity is blocked by wortmannin and rapamycin in 3T3-L1 adipocytes: evidence for the involvement of phosphoinositide 3-kinase and p70 ribosomal protein-S6 kinase Biochem J 305: 25--28

11. Azpiazu I, Saltiel AR, DePaoli-Roach A, Lawrence JC Jr (1996) Regulation of both glycogen synthase and PHAS-1 in rat skeletal muscle involves mitogen-activated protein kinase-independent and rapamycin-sensitive pathways. J Biol Chem 271: 5033--5039

12. Dent P, Lavoinne A, Nakielny S, Caudwell FB, Watt P, Cohen P (1990) The molecular mechanism by which insulin stimulates glycogen synthesis in mammalian skeletal muscle. Nature 348: 302--308

13. Sutherland C, Leighton IA, Cohen P (1993) Inactivation of glycogen synthase kinase 3 beta by phosphorylation: new kinase connections in insulin and growth-factor signalling. Biochem J 296: 15--19

14. Tobe K, Kadowaki T, Hara K et al. (1992) Sequential activation of MAP kinase activator, MAP kinases and S6 peptide kinase in intact rat liver following insulin injection. J Biol Chem 267: 21089--21097
15. Lazar DF, Wiese RJ, Brady MJ et al. (1995) Mitogen-activated protein kinase kinase inhibition does not block the stimulation of glucose utilization by insulin. J Biol Chem 270: 20801--20807

16. Cross DAE, Alessi DR, Cohen P, Andjelkovich M, Hemmings BA (1995) Inhibition of glycogen synthase kinase-3 by insulin mediated by protein kinase B. Nature 378: 785--789

17. Chowdhury MH, Agius L (1987) Epidermal growth factor counteracts the glycogenic effect of insulin in parenchymal hepatocyte cultures. Biochem J 247: 307--314

18. Peak M, Agius L (1994) Inhibition of glycogen synthesis by epidermal growth factor in hepatocytes. The role of cell density and pertussis toxin-sensitive GTP-binding proteins. Eur J Biochem 221: 529--536

19. Welsh GI, Foulstone EJ, Young SW, Tavare <' JM, Proud CG (1994) Wortmannin inhibits the effects of insulin and serum on the activities of glycogen synthase kinase- 3 and mitogen-activated protein kinase. Biochem J 303: 15--20

20. Stokoe D, Caudwell B, Cohen PTW, Cohen P (1993) The substrate specificity of mitogen-activated protein (MAP) kinase-activated protein kinase-2. Biochem J 296: 843--849

21. Kyriakis JM, App H, Zhang X et al. (1992) Raf-1 activates MAP kinase-kinase. Nature 258: 417--421

22. Anderson NG, Maller JL, Tonks NK, Sturgill TW (1990) Requirement for intergration of signals from two distinct phosphorylation pathways for activation of MAP kinase. Nature 343: 651--653

23. Dopore <' F, Vanstapel F, Stalmans W (1980) Glycogen synthase phosphatase activity in rat liver. Two protein components and their requirement for the activation of different types of substrate. Eur J Biochem 104: 137--146

24. Alessi DR, Cuenda A, Cohen P, Dudley DT, Saltiel AR (1996) PD 098059 is a specific inhibitor of the activation of mitogen-activated protein kinase kinase in vitro and in vivo. J Biol Chem 270: 27489--27494

25. Chung J, Grammer TC, Lemon KP, Kazlauskas A, Blenis J (1994) PDGF- and insulin-dependent pp70(S6k) activation mediated by phosphatidylinositol-3-OH kinase. Nature 370: 71--75

26. Weng QP, Andrabi K, Klippel A, Kozlowski MT, Williams RT, Avruch J (1995) Phosphatidylinositol 3-kinase signals activation of p70 S6 kinase in situ through site-specific p70 phosphorylation. Proc Natl Acad Sci USA 92: 5744--5748

27. Cross DAE, Alessi DR, Vandenheede JR, McDowell HE, Hundal HS, Cohen P (1994) The inhibition of glycogen synthase kinase-3 by insulin or insulin-like growth factor 1 in the rat skeletal muscle line L6 is blocked by wortmannin, but not by rapamycin: evidence that wortmannin blocks activation of the mitogen-activated protein kinase pathway in L6 cells between Ras and Raf. Biochem J 303: $21--26$

28. Alessi DR, Andjelkovic M, Caudwell B et al. (1996) Mechanism of activation of protein kinase B by insulin and IGF-1. EMBO 15: 6541--6551

29. Howell SR, Hazelton GA, Klassen CD (1986) Depletion of hepatic UDP-glucuronic acid by drugs that are glucuronidated. J Pharmacol Exp Therap 236: 610--614

30. Lawrence JC Jr, Roach PJ (1997) New insights into the role and mechanism of glycogen synthase activation by insulin. Diabetes 46: 541--547

31. Eldar-Finkelman H, Argast GM, Foord O, Fischer EH, Krebs EG (1996) Expression and characterization of glycogen synthase kinase-3 mutants and their effect on glycogen synthase activity in intact cells. Proc Natl Acad Sci USA 93: 10228--10233

32. Yang L, Camoratto AM, Baffy G, Raj S, Manning DR, Williamson JR (1993) Epidermal growth factor-mediated signaling of G(i)-protein to activation of phospholipases in rat-cultured hepatocytes. $\mathbf{J}$ Biol Chem 268:3739--3746

33. Alessi DR, Cauldwell FB, Andjelkovic M, Hemings BA, Cohen P (1996) Molecular basis for the substrate specificity of protein kinase B; comparison with MAPKAP kinase-1 and p70 S6 kinase. FEBS Lett 399: 333--338 